\title{
Montréal, Creative City and Immigrant Creatives: Can the Art World and Entrepreneurship Be Brought Together?
}

\author{
Diane-Gabrielle Tremblay*, Ana Dalia Huesca Dehesa \\ Téluq, Université du Québec, Montreal, Canada \\ Email: "dgtrembl@teluq.ca \\ Received 25 January 2016; accepted 20 May 2016; published 23 May 2016 \\ Copyright ( 2016 by authors and Scientific Research Publishing Inc. \\ This work is licensed under the Creative Commons Attribution International License (CC BY). \\ http://creativecommons.org/licenses/by/4.0/ \\ (c) (i) Open Access
}

\begin{abstract}
In 2006, Montreal joined the Creative Cities Network as was named "UNESCO City of Design". Since the tabling of the report of Richard Florida on Montreal, the city wished to move towards the objective of the Creative City, as did many cities internationally. In this context, the city of Montreal was trying to attract and retain creators so that they could develop their careers and contribute to this Creative City image. We analyzed the particular situation of immigrant artists and creators and the way they built their career in Montreal. As other artists and designers, they moved between the art world and the world of entrepreneurship, two apparently conflicting worlds, which they needed to bring together for a successful career, and this was their main challenge.
\end{abstract}

\section{Keywords}

Creative City, Creators, Immigrants, Creativity, Entrepreneurship, Management, Risk, Uncertainty

\section{Introduction}

In 2006, Montreal joined the Creative Cities Network as was named "UNESCO City of Design” [1]. Since the tabling of the report of Richard Florida on the city of Montreal [2], Montreal wished to move towards the image of the Creative City [3]-[8], as do many cities internationally [9]. In this context, the city of Montreal is trying to attract creators so that they can develop their careers and contribute to this creative city. We are interested in the particular situation of immigrant artists and creators and the way they try to build their career in Montreal, moving, like other artists and designers, between the art world and the world of entrepreneurship or business [10] [11]. In the current environment, a situation of insecurity and financial risk is characteristic of creative careers.

${ }^{*}$ Corresponding author.

How to cite this paper: Tremblay, D.-G. and Dehesa, A.D.H. (2016) Montréal, Creative City and Immigrant Creatives: Can the Art World and Entrepreneurship Be Brought Together? Journal of Human Resource and Sustainability Studies, 4, 55-67. http://dx.doi.org/10.4236/jhrss.2016.42007 
[12].

This article thus extends the reflections on the Creative City mentioned above and others [13]-[15], and creative careers [16]-[18]. We begin with a general introduction to the theory of the creative city and the creative class, to fully contextualize our interest in creative careers, then we expose the research methodology before turning to the challenge of bringing together the art world and the entrepreneurial world in the context of a creative career [19].

We need to recognize that creative professionals of immigrant origin have knowledge and specific skills that are related to their cultural background and help them develop the business in different ways. But once they are in the new host society, they need external resources to produce and deliver their artistic products [20]. In this context, social networks are a fundamental external resource; they provide support, information on the local business culture and how to access the distribution channels [16]. Thus, the success and performance of immigrant entrepreneurs in cultural businesses depend on their integration in the networks of local businesspeople.

\section{The Creative City and Creators}

We start by presenting a few elements related to the theory of the "Creative City". It should be mentioned that the writings on this subject are quite numerous and are located at the crossroads of various disciplines such as urban studies, urban geography, urban sociology and even economics. We therefore present only the most relevant aspects for our research.

We must go back to the era of the Arts and Crafts movement in the late nineteenth century to find the first writings on creativity and its relationship with the city. In the culturalist vision then put forward, space changes according to the spiritual needs of the individual, and the community plays a vital role in the development of cities that are seen as complex organisms [21].

From the 60s on, the urban sociologist Jane Jacobs is the first to speak of "creative cities"; her thesis is particularly well exposed in her book "Cities and the Wealth of Nations" [22]. She studied innovative cities, and showed how they were strongly based on a diverse population and elements related to "serendipity" or chance meetings. During the 90s, Jacobs's research contributed to changing the urban development of some city centers in North America, and she inspired many researchers in the development of a new approach to territorial governance policies.

Jacobs observed the urban environment of the city in North America and the conditions that influence urban diversity. She argues that the diversity and the exchange of ideas are essential for the creation of a powerful and dynamic urban vitality. Jacobs also observed that the different ethnic and economic realities of a local context are beneficial to the community. Indeed, from her point of view, diversity is a source of creativity and innovation. She speaks of a cultural space which is "self-reproductive" that is to say that it is based on the principle of "learning by doing”. In such a context, exchanges between people of different cultures produce an effect of contagion and imitation and ensure the constant development of new ideas [23].

Glaeser [24] argues for his part that in cities that work well we find cultural and industrial diversity, a diversity that can often borrow and imitate. This suggests that the presence of immigrant creators contributes to the diversity of the creative city, and therefore constitutes a positive contribution to creativity and innovation.

According to Jacobs, at the neighborhood level, it is the sum of chance contacts, generally spontaneous, which create a feeling of a collective personality among the inhabitants and eventually create a climate of respect, the absence of which is catastrophic for street life, but which research cannot create or institutionalize [25] Like Jacobs, Glaeser [24] argues that the concentration of population is the vector of innovation and productivity for the city. The author speaks of urban anonymity and says people can develop as they wish in relation to people around them, which is not necessarily the case in a smaller environment.

This vision is shared by Gladwell [26], who argues that social isolation has serious consequences on the wellbeing of individuals and neighborhood safety. He adds that the anonymity of urban life and the sense of alienation that it generates make people insensitive [27]. Jacobs suggests that trust between people is fundamental to the vitality of a neighborhood. In strategic planning processes, this feeling is a basis for structuring a stable and balanced base of social capital [25] between the different actors of a given territory (citizens and various public and private interest organizations).

According to Jacobs [25], each city has its own "personality”, with various areas developing their personality through the spontaneous coming together of people for a common purpose. Jacobs has drawn her conclusions 
from the observation of an urban experience based on a self-organized movement in the vibrant East Village of New York. Shortly before the publication of her first book, the urban planning commission of New York announced a major reconstruction and redevelopment program aimed at revitalizing an abandoned sector of the East Village neighborhood. Jacobs and the community neighborhood, made up of artists, writers, Puerto Rican and Italian-American immigrants, strongly criticized this type of urban renewal policy and they reacted by creating a spontaneous movement to try to reverse the municipality's project.

With this example, Jacobs [25] recalls that in most cases the "bulldozer planning approaches" produce a negative effect. She adds that major urban development projects which start from the top and are then imposed upon the population, in a top-down approach, are a major source of the problem, with catastrophic consequences for cities.

Richard Florida also criticized severely the large-scale programs of revitalization of city centers [7]. In a poorly regulated urban context, interactions and behaviors of certain groups may have a negative impact on cities. On the contrary, to build an "urban climate" conducive to attracting new creative talent, which are essential to the community, municipal and cultural policies should aim to stimulate the interaction between individuals, in order to support creativity and to enrich the cultural diversity. In addition, cities should provide structures as well as physical capital, investment in cultural facilities with high symbolic value and encourage "feedback" from the street.

According to Florida [7], there is no magic solution to build the kind of communities and organizations which are required by the creative era and creative city projects. However, some criteria can create the necessary premises for redevelopment or revitalization of certain neighborhoods or cities. One can explore new approaches based on arts and culture.

Landry [4], for example, describes a strategic urban planning method based on seven groups of factors that partially overlap those of Jacobs [25] and Florida [6]. They identify as factors contributing to the creative city model: creative individuals, will and leadership, diversity of talent, genuine organizational culture, support of local identity, urban spaces and structures, as well as networking.

\subsection{The Creative Class}

In his book "The Rise of the Creative Class", Florida speaks of the creative drivers of a society and identifies the conditions for achieving this result. His analysis is based on the "creativity index", reporting on what he called the "Three Ts". He writes that cities that accumulate talent, that are tolerant and develop technology are those that will experience a strong socio-economic development. According to Florida [7], the most powerful creative centers produce a creative climate and a high level of artistic and cultural dynamism which ensures, consequently, an increase in employment and the demographics of the city.

Employment in the cultural sectors is often prone to ups and downs. Indeed, while employment appears to have increased in the beginning of the 2000s, it declined from 2009, mainly because of the negative effects of the global recession [27].

The Conference Board of Canada also suggested that total employment in cultural occupations increased by 5.1\% from 2000 to 2010. The Conference Board indicates that the technical and operational occupations and those in the creative and artistic sectors have experienced the highest growth (5.3\%). In 2009 however, employment declined in all groups of cultural occupations, except occupations related to the preservation of heritage [27].

Florida follows Jacobs' theories but refers to the concept of human capital; he stresses that there is a link between a human climate and the attraction of a new class of people with a "creative ethos", which he calls the "creative class". Florida indicates that this is a community made up of various groups of professionals, that is to say professional clusters coming together in places that are characterized by openness and tolerance, as is often the case in urban centers where populations are open to multiculturalism [28].

Florida [6] argues that artists and creatives represent 30\% of workers in the United States. Florida indicates there is a "very creative" core, and also various creative "professions". Florida defines the dominant social themes of this class, whose roots are also in the group of "Bobos" or bourgeois/bohemians. According to Florida, these are people who are characterized by their open view on the world. This group of people is seen as having a new culture based on values that combine concerns for ecology, personal development and values of tolerance and respect. The creative class is thus composed of individual producers of creative ideas, people of different 
ages, ethnicities, civil status and sexual preferences. The diversity of such a population is what contributes to spark creativity and Florida adds that these creative communities often include a good number of singles and gays. The essence of the theory is that the creative class is diverse and that this diversity contributes to an innovative and creative city [6] [7].

Creative communities are thus characterized by a strong cultural capital as well as values of individualism and meritocracy; moreover, they attach great importance to open and competitive, challenging as well as flexible work, in the context of a "cool space".

Some critiques were presented to the vision of the creative class [29], but the importance of the diversity of populations for creativity remains a determinant characteristic of the theory of the class and the creative city. As mentioned above, this includes ethnic or cultural diversity, amongst other forms of diversity, and this is what brought us to look into the integration of immigrant creatives in the Montreal region, as we will do further on, after a last theoretical section on the challenges of economic development in the perspective of the creative city.

\subsection{The Challenges of Economic Development and the Creative City}

Development challenges of the creative economy are complex. They present a paradox, namely the importance of developing creative industries to promote economic growth, but also a possible instrumentalization of culture and the arts for the benefit of the economy, without the creatives benefitting from this development. Many critics argue that there is a strong risk of instrumentalization of culture in favor of economic development. Research on artists and creatives allows us to understand what is at stake in this possible clash between economy and culture [11].

In our research on immigrant creators, we wanted to see to what extent immigrant creatives can contribute to the development of the creative city, while at the same time building their own career. In a report commissioned by the city of Montreal, Stolarick, Florida and Musante [2] present ideas to attract creatives and artists. With economic development as the main objective, the concept of the creative city is often presented in a context of urban competitiveness or liberal policies favoring growth, without necessarily integrating groups that may possibly be excluded [29]. The issue of social cohesion or "living together" is not necessarily included in the Creative City project, although some authors do call for an integration of this perspective [29]. This is all the more pertinent as we are interested in the situation of immigrant creatives. This is what led us to focus on this particular group, i.e. immigrant creatives, after conducting a number of studies on various groups of creatives, but without integrating this dimension of diversity related to ethnicity and immigration.

Our research thus looked into the trajectories of immigrant artists and creatives in the context of the development of the project of Montreal as a creative city. We argue that the city and various intermediary organizations can help support the careers of immigrants creatives and we are particularly interested here in the development of the dual professional identity of the creatives: an identity which is simultaneously entrepreneurial and artistic.

Since we are dealing with the role of creatives and artists in the development of the creative city, we need to analyze this paradox of a possible conflict between creativity and economics (or entrepreneurship) in the creative context. Thus, while local governments often wish to develop the economy and creative careers, reality presents a paradox, even an opposition or conflict between the creative dimension and entrepreneurial dimension. There appears to be a tension between creative freedom and commercial obligations. To a certain extent, commercial obligations can impede creativity, creative processes being difficult to plan and control. This is why they are often viewed as conflicting, while at the same time both dimensions appear fundamental for a creative career to succeed.

\section{Methodology}

The research we conducted on immigrants creatives is in continuity with other work on the creative professions, including references mentioned above, by Florida, Markusen, Scott and others. Our field survey is based on interviews with 21 artists (12 men and 9 women), but 19 of which were more complete and have been used more in the analysis and in this paper (Tables A1-A3). We also met with 12 intermediary organizations working with immigrant artists and creatives to better understand the support and assistance that could be offered to them, but also to understand the perception of these organizations on the professional integration of immigrant creatives in Quebec.

The research is based on semi-structured interviews, using a grid that we had used in previous research with 
creatives from various sectors (film, fashion, multimedia, etc.), but adapted in order to identify the specific difficulties, challenges and realities of immigrant creatives. The interviews lasted an average of 1 hour, between 45 minutes and 1 hour 30 minutes approximately. All the interviews were transcribed, and they were then the subject of analysis.

The interviews were analyzed manually using a method of thematic content analysis. We established an inventory of the various opinions and ideas expressed, and then we selected the most pertinent sentences, which can be described as "key-phrases". This analysis allowed us to highlight the visions and representations of respondents favoring an individualized interpretation of what was said, but also an analysis of the dominant trends.

\section{Results}

In this article, we mainly rely on the words of our creative and artistic respondents, although interviews with organizations have also contributed to the analysis and to draw some conclusions. We will address various aspects regarding the results, starting with the artistic dimension of the work of the creatives and the challenge related to the business side of the activity, or the entrepreneurship dimension, a challenge which was put forward by many respondents. We will then move to elements that seem essential to try to overcome the opposition between the creative dimension on the one hand and a successful immigrant entrepreneurial and creative career on the other, in the objective of contributing to the diversity of the city as well as to the emergence of the creative city.

\subsection{The Artist as a Creative}

The dimension of creativity is essential for artists and creatives, for immigrant creatives as well as for the others. Our interviewees all emphasize that creativity is an essential element for them, regardless of their status, that is to say they whether they are entrepreneurs or employees in the creative and artistic fields. Some quotes confirm the importance of the artistic dimension:

"Creativity is more on the artistic side, to do the work I love to do, that is to create, develop and build houses, or other custom applications, according to customer needs” (Participant no 13, MEX, Artist).

"I've always been passionate about art, my father always had a passion for photography, everything is connected to art and creativity, for visual effects” (no 25 PAK MMD $^{1}$ ).

"I'm oriented towards creativity, I prefer to develop or create new projects, but I did not really like the experience of being self-employed" (no 16, CUB, Artist).

"I worked for a magazine which sells fabrics and buttons, and I could bring my knowledge of aesthetics, to help customers and designers to choose fabrics, buttons and accessories; because of my work in the theater, I had developed this competence" (no 30, ARG, Artist).

"I enjoy working in a creative environment, in video games... the characters, the different ways of seeing things. Innovation comes with technology, if there is a new platform, which improves video games or animations, we can make more realistic images, have a better definition of images...” (no 22, COL, MMD).

However, many have difficulty dealing with the uncertainty of this creative or artistic career, as this quote suggests:

"I'm good in photo, in video, in my culture weddings are very colorful, so I thought, I can do wedding photos; I told myself, if I ever decide to be an entrepreneur I can open a photography company and do video for weddings or other events. I'm always mad at the end of my contracts, I think I could make this work for me to get a guarantee income" (no 25 PAK, MMD).

Despite these uncertainties, the artists and creatives not only strongly value creativity, but hope to develop it further over the years. However, especially in the short term, many had to accept other types of jobs, full-time or part-time part, to meet their immediate needs. However, they hope to return to this most creative dimension afterwards:

"I’m happy, I have been a coordinator, I could manage daily, I hope I can be artistic director, to really

${ }^{1}$ See the first table in the Appendix for the precise meaning of the various elements of classification. 
work in my field" (no 18, BRA, Artist).

"The mobility that I had is vertical, it served to open new doors for me and to help me move forward" (no 22, COL, MMD).

Many immigrant artists and creatives think that by working hard, over the years, they'll get their way and gain a reputation in their creative field; they clearly do not want to abandon their creative career and they consider that working hard is the only way to succeed:

"The opportunities are huge, it is the result of hard work, the more you want to work, the more you will succeed, but the more you want to be lazy, the less you will succeed. There is no limit. For example, everyone I look at who is at a senior level, they took between 8 and 10 or 12 years to get up there, it depends on the number of hours you'll put in your work; your passion will help you communicate your ideas, be more confident and have more responsibilities to go up the ladder" (no 25 PAK, MMD).

\subsection{The Entrepreneurial Dimension}

Beyond the artistic dimension, the creatives clearly see that they must somehow be entrepreneurs or at least have a feel for the business aspect of their activity. As was observed for Québec artists, immigrants also sometimes experience difficulties in facing the integration of the entrepreneurial dimension, which sometimes seems alien or useless to them, but most of those we interviewed believe that this is essential to the success of their creative project:

"I am more oriented towards creativity but we must look at the business side, I calculate my expenses and have to get organized" (no 31, FRI, Artist and MMD).

Some have a trusted person who can assist them in this business dimension or even assume this role of entrepreneur:

"I visualize my career as a singer with a solid structure; if we want to work, I have learned to rely on budget management. I am fortunate to have a partner who is my boyfriend, who is a pretty structured person, who is a visionary, and he helps me make decisions at the right time. For example, with broadcasters, who are paying the concert, he will take care of this part, because to me these are things that I do not really understand, they are not in my field. So it is a team work, we need a business plan. It is a business, yes, we have freedom in the artistic dimension, but we need a structure, and things have to be clear and well organized. My boyfriend is my manager” (no 27, MEX, Artist).

The majority of creatives must integrate this entrepreneurial dimension into their own work, either because they have no trusted person to take care of this confidence or because they do not have the resources to pay someone else. They often recognize that it's not always easy to integrate creativity and entrepreneurship, and there is sometimes a conflict between these two dimensions:

"I learned the entrepreneurial skills and the overall management of the entire company, for example: budget management, the payment of debts, creating songs and shows, interviews, etc.” (no 27 MEX, Artist).

"The entrepreneurial side that I built in my practice, it’s a bit that I am able to pick up contracts, to bargain, and bargain. For example, besides my formal job, I work as a volunteer in the media, there are people who approach me to make a corporate video or sometimes I host shows, so I am able to be sure of myself, and I can even say no or I can negotiate which type of contract I will accept, depending on my time” (no 16, CUB, Artist).

"I know how to do personnel management, to do a budget when I get a grant, I do the production of the show, all the logistics for the events. I have already worked with a team of musicians, I learned to delegate. I am emotionally detached from my products, my show. I can do the selling, as well as offer other services, I develop my entrepreneurial side as well” (no 19, FR, Artist).

\subsection{The Manager Creator}

The manager dimension is usually not innate nor acquired for most artists and creatives. Thus, over the years, 
they learn to integrate this dimension into their creative activity:

"Being able to adjust the budget to the amount you are given in a grant for a play, and pay the comedians, even if it's a small amount, I manage to do many things myself" (no 30, ARG, Artist).

"Once in Brazil, yes, I was a freelance, I developed some skills in accounting. I developed my project management experience, and I can now look beyond my specific part of the project” (no 18, BRA, Artist).

"I was self-employed when I worked for a TV channel in a program in Spanish. I did not really like the experience of being self-employed, I learnt how to do taxes. I developed my efficiency, I was paid for 3 hours per day so I organized myself to finish in 3 hours” (no 16, CUB, Artist).

"I learned to organize concerts, to do the promotion, establish a budget, look for contacts or music places to play, and after I contacted the artists to invite them to play with me, to rehearse with them. The day of the concert, I organize transportation, food, staging and after the show, I will divide the earnings with all the artists. You need a demo recording and one must have pictures, prepare the projects and talk with the agencies, make proposals for concerts...” (no 28 CHIN, Artist).

"The management of money and time, the agenda, you have to see how much you can spend or when to invest more. I have to determine when it's time to send an email or when to establish contacts with other artists, when to look for more contracts” (no 29, BRA, Artist).

"To be self-employed and be independent, you must do public relations, find contracts, manage customers, do communications, project management, invoices, track payments, you can develop your communication skills and all others" (no 31, VEN, Artist and MMD).

Many also noted that the failure to manage successfully can have a negative impact on their reputation and the vision that one has of their artistic ability or creativity. They realize they have to pay attention to the management and entrepreneurial dimension as well as the artistic and creative dimension:

"I had a contract and then, they gave me another contract, I said yes of course I can do it, but it was a real challenge, because I had 10 people to manage, we had to deliver on the two contacts, for the first and the second contract that rolled in parallel, so you have to turn into a kind of manager, to organize the project and sometimes it is not that obvious. Because people's habits are not always the same, for example, people do not always know how to respect a schedule. We must see things with the bank, you have to be responsible with your checks. Payroll, quality control, and to do all that is difficult. I do not always have someone to help me, and if they are happy with the quality that I have provided, I cannot drop the quality on the second contract. As long as you have a name and a reputation, you cannot put your reputation at risk. It is scary, we have only one name. I now understand all the non-artistic dimensions of the organization, the business organization and all” (no 7, CHIL, Artist).

Two of the interviewees indicated that integrating this managerial dimension seemed a little strange to them and they were somewhat surprised that they had to integrate the artistic and entrepreneurial or management dimension. They considered it may be a characteristic of the culture of Quebec or North American work culture to integrate this:

"For example to get the grant from the Arts Council of Montreal, you have to be a little entrepreneur because they always require grids, for example, details on how much your project will cost, how many sessions it will take you to develop it. I think it is a bureaucratic vision of a project, and at first I found this approach quite odd, but then you cannot go against the movement, and that's why I am interested in taking some training, for example, in Eureka. In fact, this course helps you understand how to do all this. You have to have an artistic vision, but also view things as a manager. You have to see your career as an administrator. You have to manage your career. People who are in the public administration, they are not artists, they have other types of careers and their forms require a set format, they want to see how the artist will make money, I think it is not bad...” (no 29, BRA, Artist).

One respondent believes that there is a different cultural identity, a specific way of doing things in order to get financing from the Québec and Canadian cultural institutions: 
"It's a question of cultural identity, to understand that we are in a territory in which those who have the power and control are white francophones, and we must know how to interpret what they ask of us. If I am going to present a film project at the National Film Board, I need to take this into account, understand the people who have the power to say, okay, well, do your project, go ahead! You will have a budget of $\$ 4,000 \$ 5,000$. You have to understand the politics, the fact that this group of people has to spend money and that's a job in itself. You have to be informed and make them want to be part of this project, and know how to sell it. You need to be able to communicate, not to be afraid of your accent, not be intimidated by codes of behavior that may be different from your usual ways. You need to have a respectful behavior, and to arrive on time is essential. sometimes we think it is not important, because we are artists, but it is actually important to succeed" (no 7, CHIL, Artist).

Cultural identity refers to generalities and particularities of cultures, and to go beyond a comparative analysis between one culture and another, it is necessary to develop a comprehensive explanatory analysis to determine how well the immigrant fits to the new culture, taking into account cultural background and history (Demorgon, 2005).

The artists and creatives therefore adapt to this requirement and try to develop their managerial skills if they want to move their projects forward. We also see that for many, it is government funding that is the main source of revenue, so they have no choice but to respect the requirements or specific forms in order to obtain funding. Thus, some designers chose to give training to help others to better cope with the demands related to the integration of entrepreneurship and creativity and learn how to structure their product and better respond to the market requirements, even in the artistic or cultural field:

"I have products, conferences, shows, that I will sell outside of Montreal. As part of my entrepreneurial training I learned to develop a structured product marketing: I share my experience with the Yemeni Jewish community. I partnered with a reporter who developed a visual and explanatory concept with me, and after I do a presentation, percussion and voice, I involve people, it is very dynamic because of my background as an animator, but I had to learn how to structure all this in a clear product” (no 19, FR, Artist).

\section{Conclusions}

Our work has shown that the image of the artist and the creative has changed dramatically in recent decades. Indeed, in the past twenty years there has been a significant change in the creative industries, the creatives have had to adapt to this context, and to move from the image of a technician or craftsman to that of the artist, then becoming more of an entrepreneur [30]. The confrontation with entrepreneurial and management issues is a major challenge for our immigrant artists and creatives, as for other creatives, but they have a few more challenges, since they do not know the local culture as well, and the business style also has to be acquired. For many artists, combining the artistic and the entrepreneurial is not an easy thing to do. Most of them really want to remain close to their creative and artistic identity, while the managerial and entrepreneurial dimensions are often more alien to them. Nevertheless, through the course of their career and integration into the local community, they realize that if they are to be part of the "Creative City" project and image, they need to combine the entrepreneurial and artistic skills.

In the creative sector, where careers are characterized by risk and uncertainty, artists need to find methods to reduce risk and uncertainty. We saw in our research that the image of the creator or the creative class [6] is increasingly being combined with the entrepreneurial image. We are well past the image of the independent creator-artist, moving towards the "creative entrepreneur" concept, and this trend seems to have gained the immigrant artists and creatives just as much as the others. Indeed, the financial and entrepreneurial dimensions are taking more and more space in their professional identity. This creative entrepreneur thus constitutes a new form of creative career in the context of the Creative City project and immigrant creatives that have come to Montreal in recent years find themselves having to adapt to this dual model of the creative entrepreneur, something which many find challenging, as other research has shown [31]. The creative immigrant must, like other creatives, fact the challenge of being an entrepreneur in addition to continuing to develop his creativity. So if creativity is the key to career success, as in all creative careers, this is not enough. Entrepreneurship and creativity are increasingly intertwined in today's creative city model and the challenge of this arrangement of two elements that can be seen as opposites [10] arises as much if not more, in the case of the immigrant creatives, since they face fur- 
ther difficulties. Indeed, they face other difficulties such as: lack of knowledge of both official languages, the non-recognition of qualifications and experience acquired abroad, the lack of Canadian work experience, discrimination, excessively specific requirements of employers and lack of professional networks [32].

All these supplementary challenges make it difficult for them to integrate the artistic and entrepreneurial cultures on top of all this, but we have seen that most are very keen on developing these new competencies in order to be able to be successful in their creative career, and to contribute as much as they can to the Creative City paradigm.

\section{References}

[1] Rantisi, N. and Leslie, D. (2006) Branding the Design Metropole: The Case of Montréal, Canada. Area, 38, 364-376. http://dx.doi.org/10.1111/j.1475-4762.2006.00705.x

[2] Stolarick, K., Florida, R. and Musante, L. (2005) Montréal, ville de convergences créatives: Perspectives et possibilités. Montréal International, Montréal.

[3] Hall, P. (2000) Creative Cities and Economic Development. Urban Studies, 37, 639-649. http://dx.doi.org/10.1080/00420980050003946

[4] Landry, C. (2000) The Creative City: A Toolkit for Urban Innovators. Earthscan, Londres.

[5] Landry, C. and Bianchini, F. (1995) The Creative City. Demos, London.

[6] Florida, R. (2002) The Rise of the Creative Class: And How It's Transforming Work, Leisure, Community and Everyday Life. Basic Books, New York.

[7] Florida, R. (2005) The Flight of the Creative Class. The New Global Competition for Talent. Harper Business, New York.

[8] Scott, A.J. (2006). Creative Cities: Conceptual Issues and Policy Questions. Journal of Urban Affairs, 28, 1-17. http://dx.doi.org/10.1111/j.0735-2166.2006.00256.x

[9] UK Trade \& Investment Dept. (2009) Creative Industries. UK Trade \& Investment Dept., London, 90.

[10] Caves, R. (2000) Creative Industries: Contracts between Art and Commerce. Harvard University Press, Cambridge (Mass).

[11] Throsby, D. (2001) Economics and Culture. Cambridge University Press, Cambridge.

[12] Markusen, A., Schrock, G. and Cameron, M. (2004) The Artistic Dividend Revisited. Humphrey Institute of Public Affairs, University of Minnesota, Minneapolis.

[13] Florida, R. (2008) Who’s Your City?: How the Creative Economy Is Making Where You Live the Most Important Decision of Your Life. Random House, Toronto.

[14] Scott, A.J. (2002) Competitive Dynamics of Southern California’s Clothing Industry: The Widening Global Connection and Its Local Ramifications. Urban Studies, 39, 1287-1306. http://dx.doi.org/10.1080/00420980220142646

[15] Markusen, A. (1996) Sticky Places in Slippery Space: A Typology of Industrial Districts. Economic Geography, 72, 293-313. http://dx.doi.org/10.2307/144402

[16] Storper, M. (1997) The Regional World, Territorial Development in a Global Economy. Guilford Press, New York.

[17] Markusen, A. and David, K. (2003) The Artistic Dividend: The Arts’ Hidden Contributions to Regional Development. Humphrey Institute of Public Affairs, University of Minnesota, Minneapolis, $42 \mathrm{p}$.

[18] Markusen, A., Schrock, G. and Cameron, M. (2004) The Artistic Dividend. Humphrey Institute of Public Affairs, University of Minnesota, Minneapolis, 28 .

[19] Davel, E., Lefevre, F. and Tremblay, D.-G. (2007) Carrière artistique et entrepreneuriat: la créativité comme voie de recherche. 5th International Congress of the Academy for Entrepreneurship, Innovation and Entrepreneurial Practices, 4-5 October 2007, Sherbrooke, 25.

[20] Thai, M. and Turkina, E. (2013) Entrepreneurial Migration: Characteristics, Causes and Effects. Journal of Enterprising Communities: People and Places in the Global Economy, 7, 188-195. http://dx.doi.org/10.1108/JEC-11-2012-0055

[21] Tremblay, D.-G. and Pilati, T. (2008) The Tohu and Artist-Run Centers: Contributions to the Creative City? Canadian Journal of Regional Science, 30, 337-356.

[22] Jacobs, J. (1984) Cities and the Wealth of Nations. Random House, New York.

[23] Hospers, G.-J. and Van Dalm, R. (2005) How to Create a Creative City? The Viewpoints of Richard Florida and Jane Jacobs. Foresight, 7, 8-12. 
[24] Glaeser, E.L. (1997) Cities and Ethics: An Essay for Jane Jacobs. Harvard University, Cambridge.

[25] Jacobs, J. (1961) The Death and Life of Great American Cities. Random House, New York, 420 p.

[26] Gladwell, M. (2003) Le point de bascule. Transcontinental Ed., Montreal, 255 p.

[27] Cultural Human Resources Council/Conference Board of Canada (2010) Cultural Sector HR Study. Cultural Human Resources Council/Conference Board of Canada, Ottawa, 196 p.

[28] Florida, R. and Mellander, C. (2007) The Creative Class or Human Capital?_Explaining Regional Development in Sweden. Paper No. 79, CESIS, 34 p.

[29] Shearmur, R. (2006) L'aristocratie mobile du savoir et son tapis rouge. Quelques réflexions sur les thèses de Richard Florida. In: Tremblay, D.-G. and Tremblay, R., Eds., La compétitivité à l'ère de la nouvelle économie, enjeux et défis. PUQ, Québec City, 285-303.

[30] Davel, E., Lefevre, F. and Tremblay, D.-G. (2007) Carrière artistique et entrepreneuriat: la créativité comme voie de recherche. Paper Presented at the 5th International Congress of the Academy for Entrepreneurship, Innovation and Entrepreneurial Practices, Sherbrooke, 4-5 October 2007, 23.

[31] Tremblay, D.-G. and Yagoubi, A. (2014) Knowledge Sharing and Development of Creative Fashion Designers' Careers: The Role of Intermediary Organisations. International Journal of Knowledge Based Development, 5, 191-208.

[32] Bastien, Y. and Bélanger, A. (2010) Recension de politiques et expériences d'intégration en emploi des immigrants dans trois grandes RMR canadiennes d’immigration. National Institute for Scientific Research, Montreal. http://emploi-metropole.org/publications 


\section{Appendix}

Table A1. Portrait of the respondents.

\begin{tabular}{|c|c|c|c|c|c|c|}
\hline Participant & $\begin{array}{l}\text { Country of } \\
\text { origin }\end{array}$ & $\begin{array}{l}\text { Basic training in the } \\
\text { country of origin }\end{array}$ & $\begin{array}{l}\text { Basic training in } \\
\text { Montreal }\end{array}$ & Job & Male & Female \\
\hline 1 & $\begin{array}{l}\text { MEX } \\
\text { Mexico }\end{array}$ & & BFA & $\begin{array}{c}\text { Filmmaker (photo, specialist } \\
\text { camera) and media/video } \\
\text { games (employee) }\end{array}$ & $*$ & \\
\hline 2 & $\begin{array}{c}\text { FR } \\
\text { France }\end{array}$ & IT engineer & & $\begin{array}{l}\text { Multimedia/video games } \\
\text { (employee) }\end{array}$ & $*$ & \\
\hline 3 & $\begin{array}{c}\text { COL } \\
\text { Colombia }\end{array}$ & $\begin{array}{l}\text { Journalist/media } \\
\text { communicator }\end{array}$ & $\begin{array}{l}\text { Administrative } \\
\text { Officer }\end{array}$ & $\begin{array}{l}\text { Painting teacher } \\
\text { (self-employed) }\end{array}$ & & $*$ \\
\hline 4 & $\begin{array}{l}\text { CHI } \\
\text { Chile }\end{array}$ & History (not completed) & $\begin{array}{l}\text { BA in Hispanic } \\
\text { American Literature. } \\
\text { Master of Art History, } \\
\text { Film Studies Option }\end{array}$ & Filmmaker (self-employed) & $*$ & \\
\hline 5 & MEX & Architect & $\begin{array}{l}\text { Entrepreneurship } \\
\text { Training }\end{array}$ & $\begin{array}{c}\text { Architect (independent and } \\
\text { employed) }\end{array}$ & * & \\
\hline 6 & MEX & Bachelor of Arts and Design & & $\begin{array}{l}\text { Crafts/textile design } \\
\text { (self-employed) }\end{array}$ & & $*$ \\
\hline 7 & $\begin{array}{l}\text { CUB } \\
\text { Cuba }\end{array}$ & Bachelor of letters & $\begin{array}{l}\text { Communication } \\
\text { Master }\end{array}$ & $\begin{array}{c}\text { Radio and TV journalist } \\
\text { (volunteer) agent communi- } \\
\text { cation (employee) }\end{array}$ & & $*$ \\
\hline 8 & COL & Industrial design (Italy) & & $\begin{array}{l}\text { Multimedia/Video Games } \\
\text { (self-employed) }\end{array}$ & $*$ & \\
\hline 9 & $\begin{array}{c}\text { BRA } \\
\text { Brazil }\end{array}$ & Graphic Designer & & $\begin{array}{l}\text { Multimedia/graphic designer } \\
\text { (videographer) (employee) }\end{array}$ & $*$ & \\
\hline 10 & FR & $\begin{array}{c}\text { Secondary } 4 \\
\text { Private schools of art songs } \\
\text { and music interpretation in } \\
\text { Paris }\end{array}$ & $\begin{array}{l}\text { Bachelor of Music } \\
\text { and Interpretation } \\
\text { Entrepreneurship } \\
\text { Training }\end{array}$ & Singer (self-employed) & & $*$ \\
\hline 11 & FR & BFA & & $\begin{array}{l}\text { Multimedia/designer } \\
\text { (employee) }\end{array}$ & * & \\
\hline 12 & $\begin{array}{l}\text { TUN } \\
\text { Tunisia }\end{array}$ & $\begin{array}{c}\text { Bachelor of Fine Arts } \\
\text { MA in visual and media arts }\end{array}$ & & $\begin{array}{l}\text { Painting teacher (autonomous } \\
\text { and volunteer worker) }\end{array}$ & & $*$ \\
\hline 13 & COL & BA in Advertising & $\begin{array}{c}\text { Certificate in } \\
\text { Animation 3D Video } \\
\text { (CEGEP) }\end{array}$ & $\begin{array}{l}\text { Multimedia/video games } \\
\text { (employee) }\end{array}$ & $*$ & \\
\hline 14 & ARG & $\begin{array}{c}\text { Bachelor of Music in piano } \\
\text { teacher }\end{array}$ & Piano Master & $\begin{array}{l}\text { Piano teacher } \\
\text { (self-employed) }\end{array}$ & $*$ & \\
\hline 15 & MEX & $\begin{array}{c}\text { Opéra Opera } \\
\text { Jazz Jazz } \\
\text { Performing Arts }\end{array}$ & $\begin{array}{l}\text { Individual Singing } \\
\text { Lessons }\end{array}$ & $\begin{array}{l}\text { Singer, dancer and circus } \\
\text { artist (self-employed) }\end{array}$ & & $*$ \\
\hline 16 & PAK & & $\begin{array}{l}\text { December Visual } \\
\text { Arts } \\
\text { Bachelor's Degree in } \\
\text { 3D Animation and } \\
\text { Digital Design }\end{array}$ & $\begin{array}{l}\text { Multimedia/video games } \\
\text { (employee) }\end{array}$ & * & \\
\hline
\end{tabular}




\section{Continued}

\begin{tabular}{|c|c|c|c|c|c|c|}
\hline 17 & $\begin{array}{l}\text { CHIN } \\
\text { Chine China }\end{array}$ & $\begin{array}{c}\text { Bachelor of Music (China) } \\
\text { Music Management Master } \\
\text { (France) } \\
\text { Doctorate in Music } \\
\text { Management (France) }\end{array}$ & & Musician (self-employed) & & * \\
\hline 18 & $\mathrm{BR}$ & $\begin{array}{l}\text { Bachelor's degree in } \\
\text { advertising and marketing, } \\
\text { technical studies in } \\
\text { professional photography }\end{array}$ & $\begin{array}{l}\text { My artistic Practice in } \\
\text { Mastering Artistic } \\
\text { Entrepreneurship } \\
\text { Training }\end{array}$ & $\begin{array}{l}\text { Photographer } \\
\text { (self-employed) }\end{array}$ & $*$ & \\
\hline 19 & $\begin{array}{c}\text { VEN } \\
\text { Venezuela }\end{array}$ & $\begin{array}{l}\text { Bachelor of Fine Arts } \\
\text { (graphic designer } \\
\text { multimedia) }\end{array}$ & $\begin{array}{c}\text { Artistic } \\
\text { Entrepreneurship } \\
\text { Training }\end{array}$ & $\begin{array}{l}\text { Multimedia/3D (independent } \\
\text { and employed) }\end{array}$ & * & \\
\hline 20 & ARG & $\begin{array}{l}\text { BA in theater, dramatic } \\
\text { interpretation }\end{array}$ & Joaillerie Jewellery & $\begin{array}{l}\text { Theatre and jewelery } \\
\text { (self-employed retired) }\end{array}$ & & * \\
\hline 21 & $\begin{array}{l}\text { MAR MOR } \\
\text { Maroc Morocco }\end{array}$ & $\begin{array}{l}\text { Bachelor development of } \\
\text { cultural projects and theater } \\
\text { studies }\end{array}$ & & $\begin{array}{l}\text { Management of cultural } \\
\text { projects (self-employed) }\end{array}$ & * & \\
\hline $\begin{array}{l}\text { Total } \\
\text { participants }\end{array}$ & 21 & & & & & \\
\hline
\end{tabular}

\section{Table A2. Origin of the respondents.}

\begin{tabular}{cccc}
\hline Country of origin & Number & Men & Women \\
\hline MEX & 4 & 2 & 2 \\
COL & 3 & 2 & 1 \\
CHI & 1 & 2 & 1 \\
BRA & 2 & 1 & 1 \\
VEN & 1 & 1 & 1 \\
ARG & 2 & & 1 \\
CUB & 1 & 2 & 1 \\
FR & 3 & & 1 \\
TUN & 1 & & 9 \\
CHIN & 1 & 1 & 12 \\
PAK & 1 & 1 & \\
MOR & 21 & & 1 \\
\hline Total no of participants: & & & 1 \\
\hline
\end{tabular}

\section{Table A3. Intermediary organizations and Associations interviewed.}

\begin{tabular}{ccc}
\hline $\begin{array}{c}\text { Intermediate } \\
\text { bodies }\end{array}$ & Organization Name & Type of Organization \\
\hline 1 & Arts Association of Montreal Higher Schools & Non-Profit Organization (Local, provincial) \\
2 & Eureka & Non-Profit Organization (Local, provincial) \\
3 & La Vitrine (Showcase) & Non-Profit Organization (Local, provincial). \\
4 & Arts Council of Montreal (City of Montreal) & Public and para-municipal organization (Local, pro- \\
vincial)
\end{tabular}




\section{Continued}

5

6

7

8

9

10

11

12
Tohu

National Animation and Design Center (NAD Centre) of the University of Quebec in Chicoutimi (UQAC), Montreal Campus.

Culture Montreal

Artistic diversity of Montreal (DAM)

LatinArte

Artv

Department of Culture, City of Montreal

Technocompétences
Non-Profit Organization (Local, provincial)

Public Organization (Local, provincial)

Public body (local, provincial)

Non-Profit Organization (Local, provincial).

Non-Profit Organization (Local, provincial).

Public Media Organization (television) NAL.

Public body (local, provincial)

Sectoral skills committee (NAL and provincial)

Total of

organizations:

12

NAL: National; ${ }^{1}$ The Dictionary for the Census Statistical Profile of Artists in Canada defines visible minorities, Aboriginal peoples and immigrant populations as follows: Visible minorities: The Employment Equity Act defines visible minorities as "persons, other than Aboriginal peoples, who are non-Caucasian in race or non-white in color". The visible minority population is established through a question in the Census on ethnicity and race of the enumerated person, with the following response options classified as visible minorities: Chinese, South Asian, Black, Filipino, Latin American, Southeast Asian, Arab, West Asian, Japanese, Korean, Pacific Islander residents. Other responses can be specified in the space provided for this purpose. 